\title{
CUSTOMER SATISFACTION OF CUSTOMERS WITH IMPROVING MENTAL SKILLS AND AWARENESS DISCUSSED BY HUMAN RESOURCES, ESPECIALLY IN THE FIELD OF TRANSPORTATION SERVICES
}

\author{
Abi Prasidi ${ }^{1}$, Agus Yulianto ${ }^{2}$ \\ 1. STMT Trisakti, 2. STMT Trisakti \\ $\triangle$ corresponding author: prasidi393@gmail.com
}

\begin{abstract}
Human Resource Development (HR), an activity that must be implemented organization, so that knowledge (skills), ability (ability), and skill (skill) them in accordance with the demands of the work they do.

Especially in the field of Services especially transportation, where this section must have more special attention, then both the management and employees have Mental Awareness to focus and konsenterasi and always develop, innovate and Always creativity in the company's corporate satay.

Keywords: Empathy, Sense of belonging And have Customer Oriented Leadership
\end{abstract}

\section{Introduction}

Human resource development policy (HR) is part of the company's efforts to provide debriefing to its human resources in anticipation of the demands of professional HR needs. Human resource development programs through continuous education and training are indispensable. A briefing on human resource skills through education and training, is part of the provision of hard skill or hard competencies, while the demands of being a professional are not only about hard skills, but also of attitude, behavior and motivation skills.

Skills, attitudes, behaviors and motivation are soft skill development efforts that are not available in hard skill duties that generally provide skills and job skill formation. The formation of attitudes, behaviors and motivations is part of continuous learning. This continuous learning pattern is a continuation of the provision of skills that HR must possess, in an effort to prepare human resources with professional skills in performing their duties according to company needs. This kind of learning development model should be anticipated by every boss in every field of work. The key to successful development of this model of learning is the responsibility of every boss to develop each of his subordinates towards the development of professional skills. This is considering the need for professional HR 
manpower is a demand that is not inevitable demand in the era of globalization.

The demand for professionalism in service for companies engaged in public service, becomes an absolute demand to be met, the society is now increasingly critical. Especially in the field of public pelavanan, the needs of professional human resources capable of melavani well be a necessity that must be owned by companies in public service (public service) in general and transport service companies in particular.

The policy of the company to place service as the main factor for the company engaged in the field of public services, contains the consequence that this company must prepare HR owned into a professional human resources that will provide the best service quality to each consumer.

The policy of enhancing the development of professional human resources to provide services on the basis of better mental awareness (empathy) to the consumer is the implementation of the provisions of applicable legislation. These provisions bind all companies engaged in public services, such as PT. Kereta Api Indonesia, Perum Bulog, PT. Pertamina, PT. Telekom, Public Service Company, Aviation Company, Other Transportation Service Company and General Airport Company.

To support the policy of SDNI development in public service companies, the role of education here becomes very important. Education in improving the human resource performance implicitly contains the role and position of education is very strong, education in the context of SDNI development in public service companies as companies that take care of the public interest contains meaning not only include formal education, but also non-formal.

Non-formal education here is better understood as education carried out through work (on the job trainning). Internships or in other ways generally in direct contact with the execution of work at the workplace. This study discusses the implementation of education through employment (on the job trainning), internship or other ways that are generally directly related to the job.

Education provides a provision for a person to better understand his role and function in the workplace, in a narrower context, education provides supplies to the workforce to be able to anticipate problems that arise in the work. The higher a person's education base the easier it will be 
for him to recognize the problem in his job. The ability of workers in anticipating problems that occur in their work, demands the ability and skills to solve them. Implementation of work in the field of public services, for example, the mastery of skills in the face of consumer society and provide professional services requires that the workforce has the best service capabilities.

Policy demands the servant to improve the best form of service to the consumer, is a policy that becomes the public demand in general that must be fulfilled by SOEs public service. Policies that do not prioritize the service form better than the previous service, a company that does not care about the demands of society needs in general, and is a company that is not professional management.

In the public-owned enterprises BUMN as mentioned above, considering the functions and duties as an extension of the government, then the management of corporate management is no longer the main focus. The company's policy to improve the quality of service by placing qualified and professional human resources at the forefront, is a management effort in anticipating the demands of society's need for professional services from the company's business products concerned.

The behavior of human resource learners who continually explore and improve their competence in accordance with the demands of the task. Otherwise, the company's policy of providing service and quality of service will not be achieved.

According to Philip Kotler (2002, 143) "Service or service is any activity or benefit which a party may make to another party which is substantially intangible and does not result in the possession of something and its production may or may not be associated with a physical product".

The relationship between service, customer and customer satisfaction, according to Kotler (1994) there are 5 criteria determining the quality of services are:

1. Reliability (realibility), namely the ability of the company to perform services as promised immediately, accurately and satisfactorily.

2. Responsiveness, namely the ability of the company to help customers and availability to serve customers well. 
3. Confidence / assurance (assurance), namely knowledge, courtesy officers, and the nature that can be trusted so that customers are free from risks.

4. Empathy, namely caring to give individual attention to customers, understand customer needs, and ease of contact.

5. Appearance / physical evidence (tangible), which includes physical facilities, equipment employees, and means of communication.

Table 1. Principle of Service Management

\begin{tabular}{|l|l|l|}
\hline $\begin{array}{l}\text { (1) The profit } \\
\text { equation and } \\
\text { busi-ness Logic }\end{array}$ & $\begin{array}{l}\text { Customer perceived service } \\
\text { quality drives profit }\end{array}$ & $\begin{array}{l}\text { Decission on external efficiency } \\
\text { and internal efficiency (cost } \\
\text { and productivity of capital } \\
\text { control } \\
\text { and labor) have to be carefully } \\
\text { integrated }\end{array}$ \\
\hline $\begin{array}{l}\text { (2) Decission Ma- } \\
\text { king authority }\end{array}$ & $\begin{array}{l}\text { Decission making has to be } \\
\text { decentralized as close as possible } \\
\text { to the organization - customer } \\
\text { interface }\end{array}$ & $\begin{array}{l}\text { Some strategically important } \\
\text { decision have to be made centrally }\end{array}$ \\
\hline $\begin{array}{l}\text { (3) Organizational } \\
\text { focus }\end{array}$ & $\begin{array}{l}\text { The organization has to be } \\
\text { structured and functioning so that } \\
\text { its main goal is the mobilization of } \\
\text { recources to support the front-line } \\
\text { operations }\end{array}$ & $\begin{array}{l}\text { This my often require a flat } \\
\text { organization without unnecessary } \\
\text { layers }\end{array}$ \\
\hline $\begin{array}{l}\text { (4) Supervisory } \\
\text { control }\end{array}$ & $\begin{array}{l}\text { Managers and supervisors have to } \\
\text { support of employees }\end{array}$ & $\begin{array}{l}\text { As little legislative control procedure } \\
\text { as possible, although some may be } \\
\text { required }\end{array}$ \\
\hline (5) Reward systems & $\begin{array}{l}\text { Production of customer perceived } \\
\text { quality has to be the focus of } \\
\text { reward systems }\end{array}$ & $\begin{array}{l}\text { All relevant facet of service quality } \\
\text { should be considered, although all } \\
\text { cannot always be built into a reward } \\
\text { system }\end{array}$ \\
\hline focus & $\begin{array}{l}\text { Customer satisfaction with service } \\
\text { quality has to be the focus of } \\
\text { measurement of achievements }\end{array}$ & $\begin{array}{l}\text { To monitor productivity and internal } \\
\text { efficiency, internal measurement } \\
\text { criteria may have to be used as well; } \\
\text { the focus on customer satisfaction is, } \\
\text { howevwe, dominating. }\end{array}$ \\
\hline
\end{tabular}

Gronroos (1992) The principle of service management as mentioned above, basically refers to as much as possible seek innovation in providing services to consumers. Relationship with consumers in the next few periods is a focus of challenges that should be improved by many companies, especially companies engaged in the field of public service sense.

Making the company's staff able to serve consumers well is not an easy thing, it should be realized as a continuous learning process (tearing process). Making the staff able to provide good service to the consumer is not something that comes just like that, which can be done automatically, although in this case the service staff has had a long working period and work in the field of service is not something foreign to him. To be able to provide good service to consumers must be done through continuous learning process. Here the administrative function of education is needed in 
finding a way out for the development of the company's service staff capabilities through a sustainable learning process. If an organization succeeds in bringing together the above mentioned human beings, it would obviously be of great benefit to the quality of management. Quality management sua.tu organizations that have been in a good condition will have a positive impact for companies in the face of competition because of productivity and mental awareness of human resources into a high performance.

\section{Results and Discussion}

Based on the considerations mentioned above, the form of service that can be perceived by all layers of consumers is needed to minimize the prolonged chain of complaints consumers who selaju demand better service than ever. To know the success of developing the ability of professional human resources in relation with work values, morale, communication ability with consumer, mastery of information technology and supervision of supervisor is done by doing test of correlation to variables mentioned above. Seeing from this explanation above all about mental attitude in service such as public transportation transportation from infrastructure, hence there are few examples of analysis from Consumer Satisfaction of Aviation Services at Era of Cheap Rate, Consumer Satisfaction Study on Quality of Transjakarta Public Transportation of Busway Corridor I Route Block M - City and Taxi Driver Taxi Satisfaction Attitudes on Sales Tax Transportation Service System in DKI Jakarta.

The main problem of this problem is formulated simply as follows, how the level of customer satisfaction on domestic flight service performance in the era of cheap tariff? The primary data collection method was conducted by questionnaire media, with valid sample of 276 passengers on JKT-SUB route from 300 distributed questionnaires, including passengers from Garuda Indonesia, Merpati Nusantara Airlines and Batavia Airlines, which are expected to represent the current national scheduled airlines.

Other examples of public transportation are based on the Jakarta Macro Transportation Pattern policy, Transjakarta Busway public transport is included in the 'bus rapid transit' (BRT) group with its own separate and other routes, so that speed, safety and comfort factor become the main draw for consumers. In terms of uncovering aspects of customer satisfaction with 
Transjakarta Busway service quality by taking sample corridor I of Blok MKota route. In July-August 2006, there were 449 passengers, indicating that in general, the level of compliance between consumers' expectations and experience was high with a score of $95 \%$, which meant that consumers were satisfied with the quality of Transjakarta Busway services.

One of the real efforts made by DKI Jakarta Provincial Government to overcome the problem of traffic jam, traffic jam, air pollution caused by burning motor vehicle exhaust gas and at the same time creating a humane public transportation system and able to give good service to the society is by building Transjakarta Busway Which is planned as many as 15 corridors. Transjakarta Busway based on bus rapid transit (BRT) is an integral part of Jakarta DKI Makro Transportation Policy implementation which has been proclaimed by DKI Jakarta Provincial Government together with monorail based on light rail transit, water transport / snngai and miss-based missal transport under Land (Mass Rapid Transit Subway), and traffic restraint system.

Since January 15, 2004, the Busway Corridor I project of M-Kota Block as far as $12.9 \mathrm{~km}$ consisting of 20 bus stops has been officially operated. Acting as the operator is PT Jakarta Express Trans which is a consortium of various passenger transport companies previously crossed the line such as Perum PPD, PT Bianglala, PT Steady Safe, PT Ratax Armada, and BPW Pahala Kencana.

The construction of the Busway project includes a relatively short, about two years of planning phase. Along with the development phase. This project takes the example of Bogota, which has successfully operated Busway and is able to absorb the public of private vehicle users to move on the Busway bus-based mass transit.

The scope of the study is limited to aspects of service quality which include five dimensions, namely tangible, reliability, responseiveness, assurance and empathy. For Transjakarta Busway Corridor I cute Blok MKota public transportation, the number of respondents surveyed was 119 passengers and the questionnaires distributed research was conducted in July-August 2006, using the research instruments that have been designed in such a way with reference to his Parquam Servqual theory And Zeitmhal.

Polution of all passengers of Transjakarta Busway Corridor I Blok MKota, where according to available data, the number of passengers 
transported by TransJakarta has reached 70.000 average per day (Written by Nurachman, Head of Dishub DKI Jakarta at Busway Corridor II and III January 15 2006). Passenger capacity for one bus is 85 people with the composition of 30 seated passengers and 55 passengers standing. The number of buses operates as many as 91 units (the number of buses in the first year of operation is 56) so that if on average one bus carrying 85 people, then in one rit if the bus is operated simultaneously capable of carrying 7,735 passengers. In this case the number of samples taken random passengers (random sampling),

In the arrangement of the road transportation system, the Jakarta provincial government prioritizes 'public transportation' including Busway project as many as 15 corridors and done in stages. While the rail-based transportation system is to build LRT or Monorail on two routes, namely the Green Line that rotates in the center of the city and the Blue Line that passes from East to West.

In addition, MRT or Subway was built which the first phase of development is planned to pass water-based transportation is an alternative, that is by utilizing the existing canal or river network in DKI Jakarta, between the West Canal Flood $(9.2 \mathrm{~km})$, East Canal Flood $(23.5 \mathrm{Km})$, South Canal Flood $(9.6 \mathrm{~km})$, Cengkareng Drain $(8 \mathrm{~km})$, and Cakung Drain (10 $\mathrm{km})$.

The implementation of Nlakro Transportation Pattern, whose development is done in stages, is intended to improve the services and the provision of integrated, orderly, smooth, safe, convenient and efficient transportation services, and the expected public service standards of the Busway system are accessibility, security and safety, comfortable waiting room, minimum waiting time, high service quality and reliable information availability and an ever-increasing fleet with continuous maintenance or maintenance. Furthermore, one public transport is categorized to provide comfort to the passengers, privacy of passengers awake, travel time is relatively faster and door to door service (door to door service) is a taxi transport.

In the taxi business, there are three related parties. The first party is the operator or company, the second party driver or taxi driver, and the third party is the user of taxi or passenger services. Operators and drivers are two internal parties that support each other the implementation of taxi services 
that can provide good service to the users of taxi services. Operators and taxi drivers are the two parties who have a distinctive hubbant in operating a taxi. Achieving efficiency, increasing revenue, and quality of service to consumers/passengers.

The operational system of taxi companies, there are three types of operational systems used by taxi operators in Indonesia. The first is the deposit system (also known as the target or bulk term), the two commission systems (also known as percentages) and the three systems of ownership (also known as rental / buy / credit / individuals) terms.

Drivers or taxi drivers as spearheads to serve passengers and simultaneously make sales or generate revenue for the company, have a unique position in the relationship of cooperation with the operator or company. Therefore, in the context of the taxi company's operational system, it is necessary to know how the attitude and satisfaction of taxi drivers towards the three sales systems.

Mental attitude is an expression of feelings. 'Someone' (in this case it could be consumers, employees, managers, employers and others). It can also be interpreted that the mental attitude of the service must have the same high-mindedness, equally and equally low and all parties have 'good likat' to be 'equal' between transportation entrepreneurs, service personnel and consumers. With the aim not to harm each other which must have been mutually committed and agree (agree) according to agreement which have been agreed.

\section{Conclusion}

Guidance and improvement of mental attitude is realized in order to explore the potential and improve the quality of human resources masill stored, in order to become a productive resource.

If the coaching is successful, it can be believed that they will become productive human beings. All this will be even better if they get the opportunity to follow education and training, to improve their knowledge and skills. Later, they will become high quality human resources that will ultimately produce professional management.

Especially for the issue of airfare prices, the management of national scheduled airlines should improve the socialization of ticket prices and rules of the game to the public / prospective consumers in a transparent, 
consistent and professional manner so as not to confuse the public / consumers.

In general, the level of conformity between consumer expectations and experience is high with, in other words, consumers generally feel 'satisfied' to the quality of service Transjakarta Busway. Taxi companies can satisfy consumers / passengers in terms of service, should previously pay attention to the welfare of the driver. Between 'Internal Customer Service' and 'External Customer Service' can be automatically run simultaneously.

\section{References}

Andri, Kosasih, C. Suparwan \& Haryono. 2015. Passanger Satisfaction On The Service Provided By Halim Perdana Kusuma AirportJakarta In 2014. Jakarta: STMT Trisakti

Babrul, Kirom. 2012. Mengukur Kinerja Pelayanan dan Kepuasan Konsumen. Pustaka Reka Cipta

Byron Sharp. 2010. How Brands Grow: What Marketers Don't Know. Oxford University press Autralia and New Zeland. Melbourne. Australia

Bansal, H. S., \& Taylor, S. F. 1999. The service provider switching model (S PSM): A model of consumer switching behavior in the service industry. Journal of Service Research, 2(2), 200-218

Edwardson, S. W. Brown \& R. Johnston (Eds), Advancing service quality: A global perspective (pp. 171-180). International Service Quality Association

Gerpott, T. J., Rams, W., \& Schindler, A. 2001. Customer retention, loyalty, and satisfaction in the German mobile cellular telecommunications market. Telecommunications Policy, 25, 249-269.

Gremler, D. D., \& Brown, S. W. 1996. Service loyalty: Its nature, importance, and implications. In Advancing Service Quality: A Global Perspective

Grigoroudis, E. And Arabatzis, G. 2010. Visitors satsifactions, percepions and gap analysis: the cas of Dadialekimi-souflion National Park" Forest policy and Economics, Vol 12 no 3 pp 163-172

Grigoroudis, Evangelos and Yannis Sisko. 2010. Customer Satisfaction Evaluation: Methods for Measuring and Implementing. Springer New York

Hutcheson, G. D. 2011. Ordinary Least-Squares Regression. In L. Moutinho and G. D. Hutcheson, The SAGE Dictionary of Quantitative Management Research. Pages 224-228.

Heidi Cohen, 2011, 30 Branding Definitions -. http://heidicohen.com 
Inamullah Khan, 2012. Impact of Customers Satisfaction And Customers Retention on Customer Loyalty, International Journal of Scientific \& Technology Research Volume 1, Issue 2,

Jusuf, Suit, Almasdi, 2012. Aspek Sikap Mental dalam Manajemen Sumber Daya Manusia. Syiar Media, Edisi Keempat: Februari

Kim, H.S., \& Yoon, C.H. 2004. Determinants of subscriber churn and customer loyalty in the Korean mobile telephony market Determinants of subscriber churn and customer loyalty in the Korean mobile telephony market Telecommunications policy, 28, 751-765.

Kim, K.J., Jeong, I. J., Park, J. C., Park, Y. j., Kim, C. G., \& Kim, T. H. 2007. The impact of network performance on customer satisfaction and loyalty: Highspeed internet service case in Korea. Expert system with Applications, 32, 822-831

Lin, H. H., \& Wang, Y. S. 2006. An examination of the determinants of customer loyalty in mobile commerce contexts. Information \& management, 43, 271-282.

Lin, J. S. C., \& Wu, C. Y., 2011. The role of expected future use in relationship-based service retention. Managing Service Quality, 21(5), 535-551.

Nak Gulid, 2014. The Influence Of Satisfaction, Trust, And Switching Barriers On Thai Tourists Retention. The Clute Institute International Academic Conference. The Clute Institute

Parasuraman, A., Zeithaml, V.A. and Berry, L.L. 1985. A conceptual model of service quality and implications for future research, Journal of Marketing, Vol. 49, Fall, pp. 41-50

Rick Suttle. 2000. Characteristics of Consumer Markets by Demand Media http://smallbusiness.chron.com/characteristics-consumer-markets1418. html)

Rust, R. T., \& Zahorik, A. J. 1993. Customer Satisfaction, Customer Retention and Market Share. Journal of retailing, 69 (2), 193-215.

Rust, R. T., Zohorik, A. J., \& Keiningham, T. L. 1995. Return on Quality (ROQ): Making Service Quality Financially Accountable. Journal of marketing, 59,58-70.

Sari Mustika. 2016 .Optimalisasi Parking Stand Di Terminal 2 f Bandara Soekarno - Hatta Tahun 2015. Jakarta : STMT Trisakti

Sari Mustika. 2016. Faktor Penyebab Irregularities Penanganan Pesawat Medical Evacuation di Bandara Halim Perdanakusuma

Setiawan Indra, Majid, A. Suharto \& Yuliantini. 2015. Airport Factor In Flight Delays In Indonesia. Jakarta: STMT Trisakti

Setiawan Indra, Nusraningrum Dewi \& Pahala Yosi. 2015. Deregulasi Penerbangan dan Kinerja Perusahaan Penerbangan Niaga Berjadwal di Indonesia. Jakarta: STMT Trisakti

S. M. Keaveney, 1995. Customer switching behavior in service industries: An exploratory study. Journal of Marketing, Vol. 50. No. 2, pp. 71-82

Suharto, Abdul, Majid, 2013 Customer Service Dalam Bisnis Jasa Transportasi. PT.RAJAGRAFINDO PERSADA 
Swan, John E., Nolan, Johannah Jones: Gaining Customer Trust: A Conceptual Guide for the Salesperson. Journal of Personal Selling and Sales Management 5. 1985: 39-48.

Yen, H. J. R., \& Gwinner, K. P., 2003. Internet retail customer loyalty: the role of relational benefits. Journal of service industry management, 14(5), 483-500 